Pak. j. sci. ind. res. Ser. A: phys. sci. 2017 60(3)141-146

\title{
Catalytic Reduction of Wood Kikar (Acacia albida) by Acetosolv and Organosolv Pulping with Organic acids
}

\author{
Mohammad Tahir ${ }^{\mathrm{a}}$, Akhtar Shareef ${ }^{\mathrm{a} *}$, Shahid Bhutto ${ }^{\mathrm{a}}$ and Nisha Khan ${ }^{\mathrm{b}}$ \\ ${ }^{a}$ Centre for Environmental Studies, PCSIR Laboratories Complex, Karachi 75280, Pakistan \\ ${ }^{\mathrm{b}}$ Department of Chemistry, University of Karachi, Karachi -75270 , Pakistan \\ (received October 6, 2016; revised August 9, 2017; accepted August 16, 2017)
}

\begin{abstract}
Kikar wood (Acacia albida) of particle size $0.315-1.00 \mathrm{~mm}$ was subjected to acetosolv and organosolv pulping catalyzed by strong acid like $\mathrm{HCl}$. The selective condition for pulping is $95 \%, 0.25 \%$ catalyst $(\mathrm{HCl})$ solid/liquor ratio $(\mathrm{S} / \mathrm{L}) 1: 12.5$ for $180 \mathrm{mins}$, for acetic acid, 80\%, 0.2\% catalyst $(\mathrm{HCl}), \mathrm{S} / \mathrm{L}$ 1:12.5 for $120 \mathrm{~min}$, for formic acid, $85 \%, 0.2 \%$ catalyst $(\mathrm{HCl}), \mathrm{S} / \mathrm{L} 1: 12.5$ for $180 \mathrm{~min}$ for propionic acid, giving residues impurities but the $\alpha$-cellulose and klason lignin $58.5 \%$ and $24.1 \%$ in Kikar wood. The optimum delignification was achieved by the acetic acid as compared to other organic acids.
\end{abstract}

Keyword: wood, organosolv, acetosolv, pulping, kikar

\section{Introduction}

There is growing interest in radically different pulping methods that are based on the use of organic solvents and acids in pulping liquors. These methods are referred to as organosolv pulping processes. The application of organosolv delignification in chemical pulping has received the most attention. Studies in this area have focused on the conversion of biomass polymers into three potential chemical feedstocks: enzymatically hydrolysable cellulose, phenolic lignin polymer, and hemicellulose sugars. Some organosolv processes are reaching the stage of realistic industrial application as auxiliary methods for adding incremental hardwood capacity to existing pulp mills. Larger-scale production units may eventually evolve for pulping uniform raw material from fast-growing eucalyptus and poplar hybrid plantations (Addleman et al. 1995).

Organosolv pulping is a method to fractionate the components of fibre for further processing. In pulping, wood raw materials are treated with an organic solvent such as alcohol or organic acid to initiate delignification without sulphur. The benefits of the organosolv processes include the selectivity to separate lignocellulosic biomass components into high-value components, the suitability of acidic organosolv processes for non-wood species with high silicate contents, the absence of sulphur and simpler chemical recovery than kraft process (Chen and Biljana, 2014). In the past, organosolv processes were studied as alternative methods to kraft pulping to

\footnotetext{
*Author for correspondence; E-mail: akhtarshareef@yahoo.com
}

have produce papermaking pulps, which led to the development of several methods of producing pulp with properties similar to those of kraft pulp based on per oxyformic and peroxyacetic acid processes and have been tested at either the pilot or full scale, but none has been permanently applied at the industrial scale because of fibre quality issues, poor commercialization of byproducts, process cost-in efficiency and the corrosive nature and complicated recovery of chemicals (Rodríguez and Jimenez, 2008).

Recently, the use of different types of natural fibers to produce paper and textiles from woods and plants has been proposed. Wood and plants can be a good source of cellulose and lignin; nevertheless, the microstructural changes that happen during delignification have scarcely been studied.

Lignins were extracted from different species using organosolv process (ethanol/water). Obtained organosolv lignins were characterized by various methods to determine their composition, structure and functional groups with the purpose of evaluating their potential use for obtaining value-added compounds. The purity of organosolv lignin was determined. The total phenols content and the antioxidant power were analysed in order to know the reactivity of lignin. The solid / gas ratio was determined by nitrobenzene oxidation. In addition, molecular weight distribution, infrared spectroscopy and thermos gravimetrical analysis were carried out in order to determine the physical and chemical properties of organosolv lignins (Tahir et al., 2013). 
The cellulosic pulp can be considered as a promising market for the reinforcement of polymeric materials, ceramic and cementitious composites in addition to the paper production (Sundar et al., 2010). The use of cellulosic fibers as reinforcement in composite materials has been studied to replace synthetic fibres, especially glass fibres for different industrial applications such as packaging, automobiles and in the construction material (Patrica et al., 2014).

Considering the vegetable fibre reinforced cementitious composites, the lignin present in these fibres has an amorphous structure with high solubility in the alkaline medium. Contrarily, cellulosic pulps contain negligible amounts of that compound and therefore, it can result in a lower alkaline attack by cement to these pulps than fibrse with higher lignin content (Viviane et al., 2015).

There is a growing interest in the use of fibrous raw material derived from lignocellulosic materials such as annual plants and agricultural waste to cellulosic pulp production. The increasing environmental concerns, uncertain availability of wood fibres and potential increase in the wood costs justify the researches for alternative sources of fibres (Tahir and Akhtar, 2012).

In this study pulp production from the fast growing plant, kikar (Acacia albida) was examined for organosolv pulping with or without catalysts. The aim of this work was to study the microstructural changes that occur during the delignification of wood and plants fibres by means of microscopic techniques and image analysis. Acetosolv pulping method at different concentrations of acetic acid increasing acid concentration promoted higher levels of delignification, structural damage and the breakdown of fibre clumps (Tahir and Akhtar, 2012). In order to find the optimum cooking conditions, 18 different cooking experiments were carried out. The effect of ethanol ratio, cooking time as well as catalyst were studied. It was observed that even at lower temperature $\left(90^{\circ} \mathrm{C}\right)$, cooking without catalyst was able to cause sufficient defiberization. It was seen that the increasing proportion of catalyst and cooking temperature resulted in an increased delignification. However in the case of using $0.02 \%$ acid catalyst pulp yield and viscosity were lowered to an unacceptable level. The most important cooking factors were found to be the proportion of acid catalyst. Furthermore, the delignification performance was found to be depending on the $\mathrm{pH}$ of the black liquor. In a result, the optimum pulp properties were obtained by cooking at $180^{\circ} \mathrm{C}$ for
90 min with $50 \%$ ethanol mixture without catalyst. The pulp yield was noted as $44.49 \%$, viscosity was $892 \mathrm{~m}^{2} / \mathrm{s}$ and the Kappa number was 67.

\section{Materials and Methods}

Kikar wood was dried in an oven at $105^{\circ} \mathrm{C}$, chipped and disintegrated to a particle size of $0.315-1.00 \mathrm{~mm}$ and homogenized and stored in a desiccators. It was then extracted with benzyl alcohol to the extraction level and analysed by Tahir et al. (2007). The extracted sample was then subjected to analysis of its $\alpha$ - cellulose, klason lignin and holo cellulose content. All the parameters were measured on the basis of initial dry weight of the raw materials utilized in that particular set of experiments. Moreover, unlike conventional chemical processes, organosolv processes allow the selective separation and recovery of cellulose, hemicellulose and lignin which can be converted by chemical and bio technological means into a variety of chemicals.

The delignification of $10 \mathrm{~g}$ sample was carried out in $250 \mathrm{~mL}$ round bottom flask under reflux condition, at $110{ }^{\circ} \mathrm{C}$ under constant volume conditions using liquors containing acetic acid, water and $\mathrm{HCl}$ in different sets of experiments with different proportions.

The experiment was carried out using three different conditions for delignification media. Different concentrations of $\mathrm{HCl}$ utilized by weight as a catalyst in the delignifying liquor were using different $\mathrm{S} / \mathrm{L}$ ratio of $1: 10,1: 12.5$ and $1: 15 \mathrm{~g}$, to establish the optimum delignification conditions (the pulping time used in each case was $3 \mathrm{~h}$ or $180 \mathrm{~min}$ ) which was established after series of experiments (Usmani, 2002).

\section{Results and Discussion}

The proximate chemical analysis of kikar wood (Acacia albida) used in the present study is listed in Table 1 and was done by TAPPI standard. It shows that the values of $\alpha$-cellulose and lignin in raw materials are $60 \%$ which and $25 \%$ are on higher side while extractive

Table 1. Proximate chemical composition of kikar wood

\begin{tabular}{ll}
\hline \hline Ash & $2.15 \%$ \\
Holo cellulose & $19.15 \%$ \\
$\alpha$-cellulose & $58.55 \%$ \\
Klason lignin & $24.15 \%$ \\
Hemicellulose & $17.0 \%$ \\
Benzene alcohol & $10.69 \%$ \\
\hline \hline
\end{tabular}


content are on lower side. All these values show that this raw material is worth in investigation for paper industry.

The optimum delignification is achieved by treating the raw material with liquor containing 95\% acetic acid and $0.25 \% \mathrm{HCl}$ as a catalyst. The results depicted in Table 2 shows that $\mathrm{S} / \mathrm{L}$ ratio of 1:12.5 was suitable for pulping of kikar wood. The pulping of kikar wood is $95 \%, 0.25 \% \mathrm{HCl}$ catalyst $180 \mathrm{~min}$. catalyst time and $\mathrm{S} / \mathrm{L}$ ratio is $1: 12.5$ the selection of these conditions due to the values of klason lignin and Kappa No. of reactant fractionated the products.

The kinetics of the delignification process under the established pulping condition was studied in detail by varying the time from 15 to $210 \mathrm{~min}$ and the relevant data is presented in Table 3. It shows that bulk delignification of kikar occurs in fractionation time of $180 \mathrm{~min}$. This behaviour has been further highlighted in Fig. 1 in which percentage of residual lignin (PRL) of the fractionated product has been plotted against time of digestion (Tahir et al., 2013a). A sharp slope was observed upon fractioning upto the same delignification time, after which it fall in a constant value as shown in Fig. 2. The relationship between klason lignin and \% yield of the finished product shows the fast decreases in the yield from $79.76-51.50 \%$ with the proportional decreases of klason lignin from 17.7 to $8.61 \%$. It is therefore, concluded that optimum delignification of this raw material has been achieved in 180 min with consequent yield of $51.5 \%$.

Table 3 summarizes that different working parameters for all the experiments performed in connection with

Table 2. Establishing of conditions for pulping kikar wood with aliphatic acid

\begin{tabular}{|c|c|c|c|c|c|c|c|}
\hline Establishment of conditions & $\begin{array}{l}\text { Acetic } \\
\text { Acid } \\
(\%)\end{array}$ & $\begin{array}{l}\text { Catalyst } \\
\mathrm{HCl} \\
(\%)\end{array}$ & $\begin{array}{l}\text { Time } \\
(\min )\end{array}$ & $\begin{array}{l}\mathrm{S} / \mathrm{L} \\
\text { ratio }\end{array}$ & $\begin{array}{l}\text { Yield } \\
(\%)\end{array}$ & $\begin{array}{l}\text { Kappa } \\
\text { no }\end{array}$ & $\begin{array}{l}\text { Klason } \\
\text { lignin } \\
(\%)\end{array}$ \\
\hline Acetic acid percent & $\begin{array}{l}75 \\
85 \\
95\end{array}$ & 0.20 & 180 & $1: 12.5$ & $\begin{array}{l}74.19 \\
69.57 \\
51.50\end{array}$ & $\begin{array}{l}41.91 \\
27.93 \\
23.92\end{array}$ & $\begin{array}{l}15.26 \\
12.27 \\
8.61\end{array}$ \\
\hline Catalyst $(\mathrm{HCl})$ percent & 95 & $\begin{array}{l}0.3 \\
0.25 \\
0.20\end{array}$ & 180 & $1: 12.5$ & $\begin{array}{l}49.7 \\
51.50 \\
54.01\end{array}$ & $\begin{array}{l}44.1 \\
23.92 \\
24.61\end{array}$ & $\begin{array}{l}8.67 \\
8.61 \\
9.87\end{array}$ \\
\hline $\mathrm{S} / \mathrm{L}-$ ratio & 95 & $\begin{array}{l}0.25 \\
0.25 \\
0.25\end{array}$ & 120 & $\begin{array}{l}1: 10.0 \\
1: 12.5 \\
1: 15\end{array}$ & $\begin{array}{l}64.86 \\
51.50 \\
46.9\end{array}$ & $\begin{array}{l}44.21 \\
23.92 \\
28.73\end{array}$ & $\begin{array}{l}13.46 \\
8.61 \\
9.17\end{array}$ \\
\hline Formic acid percent & $\begin{array}{l}70 \\
80 \\
90\end{array}$ & 0.2 & 120 & $1: 12.5$ & $\begin{array}{l}53.69 \\
52.12 \\
46.98\end{array}$ & $\begin{array}{l}35.94 \\
24.76 \\
17.98\end{array}$ & $\begin{array}{l}11.55 \\
7.98 \\
8.39\end{array}$ \\
\hline Catalyst(HCl) & 80 & $\begin{array}{l}0.15 \\
0.20 \\
0.25\end{array}$ & 120 & $1: 12.5$ & $\begin{array}{l}56.91 \\
52.12 \\
44.15\end{array}$ & $\begin{array}{l}28.00 \\
24.76 \\
25.00\end{array}$ & $\begin{array}{l}9.16 \\
7.98 \\
7.78\end{array}$ \\
\hline $\mathrm{S} / \mathrm{L}-$ ratio & 80 & 0.2 & 120 & $\begin{array}{l}1: 10 \\
1: 12.5 \\
1: 15\end{array}$ & $\begin{array}{l}51.81 \\
52.12 \\
47.67\end{array}$ & $\begin{array}{l}27.44 \\
24.76 \\
25.00\end{array}$ & $\begin{array}{l}8.11 \\
7.98 \\
7.51\end{array}$ \\
\hline Propionic acid percent & $\begin{array}{l}85 \\
90 \\
95\end{array}$ & 0.1 & 180 & $1: 12.5$ & $\begin{array}{l}56.13 \\
51.27 \\
46.90\end{array}$ & $\begin{array}{l}28.19 \\
21.27 \\
17.85\end{array}$ & $\begin{array}{l}9.06 \\
8.76 \\
6.76\end{array}$ \\
\hline Catalyst $(\mathrm{HCl})$ percent & 90 & $\begin{array}{l}0.15 \\
0.20 \\
0.25\end{array}$ & 180 & $1: 12.5$ & $\begin{array}{l}52.17 \\
51.27 \\
47.90\end{array}$ & $\begin{array}{l}25.12 \\
21.27 \\
17.85\end{array}$ & $\begin{array}{l}9.25 \\
8.76 \\
6.76\end{array}$ \\
\hline $\mathrm{S} / \mathrm{L}-$ ratio & 90 & 0.20 & 120 & $\begin{array}{l}1: 10 \\
1: 12.5 \\
1: 15\end{array}$ & $\begin{array}{l}53.11 \\
51.27 \\
47.90\end{array}$ & $\begin{array}{l}25.12 \\
21.27 \\
17.85\end{array}$ & $\begin{array}{l}9.25 \\
8.76 \\
6.76\end{array}$ \\
\hline
\end{tabular}


the established procedure meet to optimum condition for kikar by organosolv pulping with acetic acid. Experiments were performed in connection with establishing the optimum conditions of \% acid, fractionates, $\%$ catalyst and $\mathrm{S} / \mathrm{L}$ ratio. It would be observed that bleachable grade pulps of Kappa No. $<30$ were obtained from experiments, in which $\alpha$-cellulose was $60 \%$ and klason lignin was rather on the higher side in raw materials (Tahir et al., 2013b).

The particle sizes are $0.315 \mathrm{~mm}$ to $1 \mathrm{~mm}$ which show that solid residue with suitable composition of $58.7 \%$ $\alpha$-cellulose and $8.61 \%$ klason lignin was obtained with high yield of $51.5 \%$ and Kappa No. 23.9 extracted with $95 \%$ acetic acid and $0.25 \% \mathrm{HCl}$ in cooking time of 180 min. For various studies during the acetosolv cooking, it was observed that all of them showed their significances during the delignification process. However, higher $\mathrm{S} / \mathrm{L}$ ratio 1: 15 has an adverse effect on the $\%$ yield and even in the quality of the fractionated product in terms of lower $\alpha$-cellulose and klason lignin. Moreover, the high concentration of acid and catalyst ( $95 \%$ acetic acid and 0.25 of catalyst $\mathrm{HCl}$ ) were selected for further kinetic study as the solid residue obtained after subsequent treatment had comparatively high \% of $\alpha$-cellulose and lower klason lignin and Kappa No.

Another operational variables studied in case of delignification of kikar wood by formic and propionic acid were percentages of acid and $\mathrm{HCl}$ as catalyst and $\mathrm{S} / \mathrm{L}$ ratios. The experiment was conducted at low temperature with the advantage of minimum cellulose and hemicellulose. Degradation and extraction of lignin is most valuable form (Santos et al., 2014). Table 2 depicts the three sets of experiments performed separately to establish optimum delignification condition in case of formic acid. The fraction time used in each case is $120 \mathrm{~min}$, established after a series of experiments. It was observed that out of three operational variable studied, value of formic acid concentration was the very effective parameter. As regards the delignified yield and extracted formic lignin concentration of formic acid increases from 70 to $90 \%$ drastically reduced the yield 52.12 to 46.98 (Table 2) in lower value of klason lignin and yield of the delignified product the concentration of $80 \%$ formic acid was selected and carried out in further experiments. The Kappa No. of product is 24.76 , which according to certain standards is bleachable (Santos et al., 2014). The selection of catalyst is $0.2 \%$ and $\mathrm{S} / \mathrm{L}$ ratio is $1: 12.5$ which is ideal for further experiments.
The kinetics of delignification of kikar wood with formic acid was depicted under the established conditions as shown in Table 3. It could be observed that increase of time had a good effect on the yield of delignified product and eventually their klason lignin / Kappa No. Moreover, it could also be seen in Fig. 1 that PRL in fractionated kikar wood samples (Table 3), gradually decrease with the increase of time of delignification.

The observation during formic acid pulping was that dignified material was quite soft not dry but it was wet, if it was allowed to dry then it returned to original state and was unsuitable for beating. It is a conventional process. When fractionation time is increased to 150 min the value of yield, klason and Kappa No. is better however, yield percentage is less.

Table 2 depicts the experiments performed for establishing the condition for optimum delignification of kikar using propionic acid. It could be seen here that the value of propionic acid is effective as compared to that of delignification of kikar wood was achieve in 180 min with respect to catalyst and charge ratio delignification. The established conditions are $90 \%$ acid $0.2 \%$ catalyst and $1: 12.5$ of $\mathrm{S} / \mathrm{L}$ ratio of propionic acid.

The kinetics of delignification of this study has been depicted in Table 3 which shows that the rate of delignification is quite drastic in the comminute of kikar wood with fractionation time as showed in Fig 2.

In Table 3 the kinetic study shows reduction of klason lignin and yield as 8.76 and 51.28, respectively the established conditions are $85 \%, 0.2$ and $1: 12.5$ at 180 min, respectively.

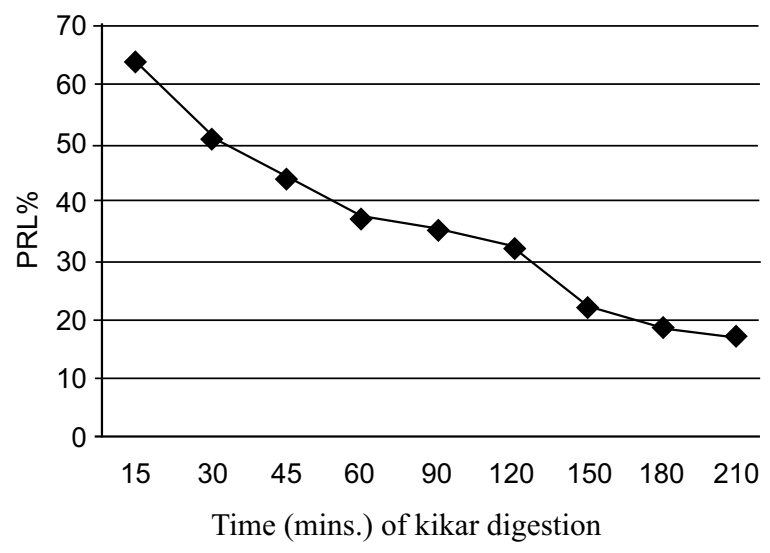

Fig 1. Plot between \% of residual lignin (PRL) and time of digestion of kikar wood with acetic acid. 
Table 3. Kinetics studies of selected conditions for pulping kikar wood with aliphatic acid

\begin{tabular}{|c|c|c|c|c|c|c|c|}
\hline $\begin{array}{l}\text { Kinetic studies of established } \\
\text { operational conditions }\end{array}$ & $\begin{array}{l}\mathrm{HCl} \\
(\%)\end{array}$ & $\begin{array}{l}\text { Time } \\
(\min )\end{array}$ & $\begin{array}{l}\mathrm{S} / \mathrm{L} \\
\text { ratio }\end{array}$ & $\begin{array}{l}\text { Yield } \\
(\%)\end{array}$ & $\begin{array}{l}\text { Kappa } \\
\text { No }\end{array}$ & $\begin{array}{l}\text { Klason } \\
\text { lignin } \\
(\%)\end{array}$ & $\begin{array}{l}\text { Residual } \\
\text { lignin(\%) }\end{array}$ \\
\hline \multirow{9}{*}{$\begin{array}{l}\text { Acetic acid } \\
95 \%\end{array}$} & \multirow{9}{*}{0.25} & 15 & \multirow{9}{*}{$1: 12.5$} & 82.89 & 44.12 & 18.71 & 64.21 \\
\hline & & 30 & & 79.76 & 38.19 & 17.70 & 58.45 \\
\hline & & 45 & & 69.37 & 37.65 & 16.10 & 42.24 \\
\hline & & 60 & & 65.91 & 33.16 & 15.50 & 42.32 \\
\hline & & 90 & & 58.52 & 30.12 & 15.32 & 35.53 \\
\hline & & 120 & & 56.04 & 26.64 & 14.60 & 32.94 \\
\hline & & 150 & & 54.57 & 25.98 & 10.11 & 22.14 \\
\hline & & 180 & & 51.50 & 23.92 & 8.61 & 18.35 \\
\hline & & 210 & & 48.98 & 23.98 & 8.60 & 16.70 \\
\hline \multirow{8}{*}{$\begin{array}{l}\text { Formic acid } \\
80 \%\end{array}$} & \multirow{7}{*}{0.20} & 15 & \multirow{7}{*}{$1: 12.5$} & 73.07 & 48.92 & 17.52 & 53.09 \\
\hline & & 30 & & 64.51 & 41.62 & 15.62 & 41.72 \\
\hline & & 45 & & 59.31 & 39.72 & 13.72 & 37.54 \\
\hline & & 60 & & 57.57 & 37.98 & 11.92 & 28.41 \\
\hline & & 90 & & 54.56 & 36.61 & 8.98 & 20.21 \\
\hline & & 120 & & 52.12 & 24.76 & 7.98 & 16.89 \\
\hline & & 150 & & 43.06 & 29.89 & 7.09 & 12.45 \\
\hline & \multirow{9}{*}{0.20} & 15 & \multirow{9}{*}{$1: 12.5$} & 77.13 & 38.30 & 17.09 & 54.58 \\
\hline \multirow{8}{*}{$\begin{array}{l}\text { Propionic acid } \\
85 \%\end{array}$} & & 30 & & 69.18 & 35.41 & 10.21 & 45.24 \\
\hline & & 45 & & 65.13 & 32.09 & 15.66 & 42.23 \\
\hline & & 60 & & 62.98 & 28.41 & 14.71 & 37.79 \\
\hline & & 90 & & 60.16 & 24.19 & 13.91 & 34.65 \\
\hline & & 120 & & 57.51 & 22.25 & 10.92 & 26.00 \\
\hline & & 150 & & 55.32 & 21.29 & 9.06 & 20.75 \\
\hline & & 180 & & 51.27 & 21.27 & 8.76 & 18.73 \\
\hline & & 210 & & 46.10 & No response & 8.56 & 16.37 \\
\hline
\end{tabular}

It is revealed that the comparatively lower concentration of $80 \%$ of formic acid was required than that of acetic

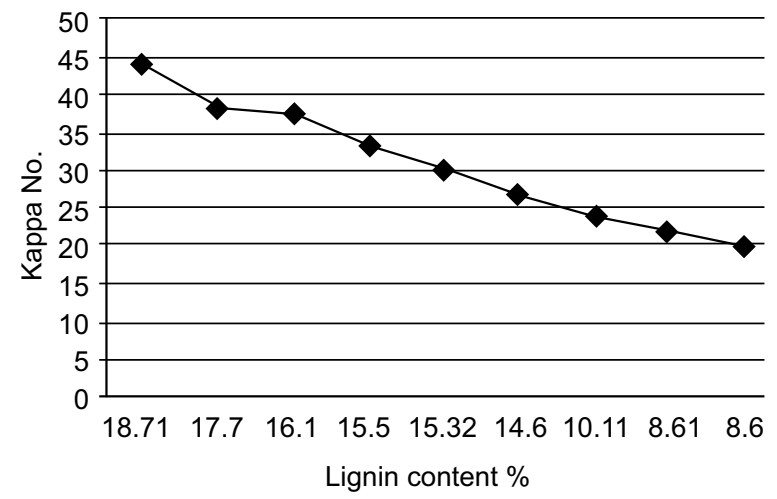

Fig 2. Plot between Kappa No. and lignin content $\%$ of kikar wood with acetic acid. and propionic acid. As the quality of the delignified product, propionic acid would give better end product in higher yield as compared to the lower aliphatic acid that was observed. There is a marked difference observed between the yield and klason lignin in fractionation, acetic, formic and propionic acid are 180, 120 and 180 min. respectively. But for propionic acid the $90 \mathrm{~min}$ shows better delignified product. The main emphasis of the study is to establish proper working conditions in a cheap and effective way by acetosolv and organosolv pulping.

\section{Conclusion}

This study concludes that kikar wood may be delignified by fractionation with three aliphatic organic acids used, but acetic acid has been found to be more suitable for delignification. Moreover, as compared to formic and 
propionic acids, it gives better quality fractionated product with lower \% residual lignin (PRL) than that of formic acid.

\section{References}

Addleman, K., Dumonceaux, T., Paice, M. G., Bourbonnais, R., Archibald, F. S. 1995. Production and characterization of Trametes versicolor mutants unable to bleach hardwood kraft pulp. Applied and Environmental Microbiology, 61: 3687-3694.

Anatoly, A., Shatalov, H. P. 2014. Dissolving grade eco-clean cellulose pulps by integrated fractionation of cardoon (Cynara cardunculus L.) stalk biomass. Chemical Engineering Research and Design, 92: 2640-2648

Chen, G., Biljana, M., Bujanovic. 2014. Impact of hotwater extraction on acetone-water oxygen delignification of Paulownia spp. and lignin recovery. Energies, 7: 857-873.

Correia, V. da C., Curvelo, A.A. da S., Marabezi, K., Almeida, A. E. F.de S., Savastano, H. Jr. 2015. Bamboo cellulosic pulp produced by the ethanol/water process for reinforcement applications. Ciência Florestal, Santa Maria, 25: 127-135.

Patrícia, S. B. dos S., Pedro, H. G.de C., Prado, R., Gatto, D.A., Labidi, J. 2014. Composition and structure of organosolv lignins from four eucalypt species. Wood Science and Technology, 48: 873885.
Rodríguez, A., Jiménez, L. 2008. Pulping with organic solvents other than alcohols. Afinidad, 65: 188-196.

Sundar, K., Vidya, R., Mukherjee, A., Chandrasekara, N. 2010. High chromium tolerant bacterial strain from Palar river basin: Impact of tannery pollution. Research Journal of Environmental and Earth Sciences, 2: 112 - 117.

Tahir, M., Shareef, A., Aziz F.A. 2013a, Delignification of sisal wood by pulping with organic acids. Pakistan Journal of Biochemistry and Molecular Biology, 46: 104-106.

Tahir, M., Khan, F.A., Shareef, A. 2013b. Acetosolv and organosolv pulping of poplar wood (Populus ciliata) with organic acids. Journal of Chemical Soceity of Pakistan, 35: 114-118.

Tahir, M., Shareef, A. 2012. Extraction of cellulose by catalytic reduction of lignin from bagasse with aliphatic acids. Pakistan Journal of Biochemistry and Biology, 45: 225-228.

Tahir, M., Khan, F. A., Usmani, T.H., Shaikh, G. H. 2007. Delignification of pakar wood (Ficus lacon Buch) by organosolv pulping with aliphatic acid like acetic acid, formic acid and propanoic acid. Pakistan Journal of Scientific and Industrial Research, 50: 299-303.

Usmani, T.H., Motan, M.T., Ahmed, M.A., Damani M.A. 2002. Acid catalyzed organosolv pulping of sunflower (Helianthus annus) stem by lower aliphatic organic acids. Pakistan Journal of Scientific and Industrial Research, 45: 34-40. 